DOI: 10.34015/2523-4552.2020.1.23

удК 343.8

Колодчина А. Л., аспірант кафедри управління безпеки, правоохоронної та антикорупційної діяльності ПрАТ «Вищий навчальний заклад «Міжрегіональна Академія управління персоналом» ORCID: 0000-0003-2820-4112

\title{
РОЛЬ ПРОКУРАТУРИ ЯК УЧАСНИКА КРИМІНАЛЬНО-ВИКОНАВЧОЇ ДІЯЛЬНОСТІ В РЕАЛІЗАЦІЇ МІЖНАРОДНИХ СТАНДАРТІВ ПОВОДЖЕННЯ ІЗ ЗАСУДЖЕНИМИ У ВИПРАВНИХ КОЛОНІЯХ УКРАЇНИ
}

У статті з'ясовано сутність і зміст діяльності прокуратури як учасника кримінально-виконавчих правовідносин, пов'язаної з реалізацією міжнародних стандартів, що стосуються засуджених, позбавлених волі, а також визначена ії роль у запобіганні нелюдського та такого, що принижує гідність, поводження і покарання щодо цих осіб.

Ключові слова: міжнародні стандарти; засуджений; прокуратура; позбавлення волі; покарання; поводження; запобігання.

В статье выяснено сущность и содержание деятельности прокуратуры как участника уголовно-исполнительных правоотношений, связанной с реализацией международных стандартов, касающихся осужденных, лишенных свободы, а также определена ее роль в предотвращении бесчеловечного и унижающего достоинство обращения и наказания в отношении этих лиц.

Ключевые слова: международные стандарты; осужденный; прокуратура; лишение свободы; наказание; обращение; предотвращение.

Постановка проблеми. Необхідність розгляду питання діяльності прокуратури як учасника кримінально-виконавчих правовідносин, пов'язаної з реалізацією міжнародних стандартів, що стосуються засуджених, позбавлених волі, у цій роботі обумовлена декількома обставинами:

а) по-перше, тим критичним станом, що склався у сфері виконання покарань України та який виступає однією з детермінант, яка негативно впливає на ефективність виконання i відбування покарання у виді позбав- лення волі та, зокрема, знижує рівень захищеності основоположних прав, свобод і законних інтересів осіб, що тримаються у виправних колоніях;

б) по-друге, об'єктивною потребою залучення всіх суб'єктів та учасників кримінально-виконавчої діяльності до процесу реформування діяльності органів та установ виконання покарань України, одним із завдань якого $\epsilon$ забезпечення реалізації на практиці міжнародних стандартів поводження із засудженими, позбавленими волі; 
в) по-третє, новим статусом прокуратури, який вона отримала у результаті видозміни Конституції України та Закону України «Про прокуратуру», які, у свою чергу, негативно вплинули на результативність здійснення нагляду за дотриманням законів у виправних колоніях України [1, c. 180-209];

г) по-четверте, завданнями, що витікають із змісту міжнародних зобов’язань України з питань, зокрема, приведення національного законодавства до законодавства Європейського Союзу;

г) по-п'яте, теоретичним переосмисленням змісту кримінальновиконавчої діяльності України у сучасних умовах та розробкою у зв'язку 3 цим адекватних науково обгрунтованих заходів з означеної проблематики дослідження.

У цьому контексті, без сумніву, досить актуальним питанням $\epsilon$ з'ясування ролі прокуратури в реалізації міжнародних стандартів поводження із засудженими у сенсі кримінально-виконавчої діяльності прокурорів, які здійснюють нагляд за дотриманням законів у сфері виконання покарань та пробації (ст. 22 КВК та ст. 26 Закону України «Про прокуратуpy»).

Постановка завдання. Саме ці обставини й обумовили вибір теми цієї статті та визначили ï головне завдання - розробити комплекс науково обгрунтованих заходів, спрямованих на підвищення ролі прокуратури у приведенні чинного кримінально-виконавчого законодавства України з означених питань до вимог законодавства Європейського Союзу.

Аналіз останніх досліджень і публікацій. Результати вивчення наукової літератури показали, що досить активно розробкою означеної проблематики займаються науковці, у першу чергу, у галузі прокурорського нагляду, а саме : В.С. Бабкова, В. Т. Білоус, Є. М. Блажівський, $\begin{array}{ll}\text { М. М. Говоруха, } & \text { В. В. Долежан, }\end{array}$ Л. С. Жиліна, П. П. Зубков, О. С. Іщук, П. М. Каркач, І. М. Козьяков, Т. В. Корнякова, М. В. Косюта, Ю. О. Новосад та інші.

Поряд 3 цим, у контексті кримінально-виконавчої діяльності, питаннями підвищення рівня участі прокуратури в кримінально-виконавчих правовідносинах не менш плідно працюють й фахівці - пенітенціаристи, зокрема: I. Г. Богатирьов, О. М. Джужа, О. Г. Колб, А. Х. Степанюк, В. М. Трубніков, І. С. Яковець та інші.

$\mathrm{y}$ той самий час, комплексних досліджень, що стосуються ролі прокуратури як учасника кримінальновиконавчої діяльності в реалізації міжнародних стандартів поводження із засудженими у виправних колоніях України, досі на доктринальному рівні не проведено, що й стало вирішальним при обранні об'єкта та предмета даної наукової розробки.

Виклад основного матеріалу. Як показали результати вивчення наукової літератури, досі на доктринальному рівні немає однозначності щодо таких категорій кримінальновиконавчого права, як: “суб'єкт» та «учасник» кримінально-виконавчих правовідносин, що важливо з огляду визначення ефективності їх діяльності у сфері виконання покарань України. Зокрема, I. В. Шмаров поряд із суб'єктами кримінально-виконавчих правовідносин пропонує розглядати як окрему правову категорію й їх учасників. При цьому, до перших він обгрунтовано відніс персонал орга- 
нів та установ виконання покарань, 3 одного боку, і засуджених до відповідних кримінальних покарань, з іншого [2, с. 35]. У свою чергу, учасниками зазначених суспільних відносин він називає всіх інших фізичних і юридичних осіб, включаючи й прокуратуру, які своїми діями сприяють діяльності суб'єктів кримінальновиконавчих правовідносин [2, с. 35].

Аналогічну позицію з цього питання займає й А. П. Гель, зазначаючи у зв'язку з цим, що межа між суб'єктами та учасниками кримінально-виконавчих правовідносин полягає в тому, що суб’єктами $є$ їх сторони, які володіють найбільшим обсягом суб'єктивних прав та обов'язків, і за їх відсутності вказані правовідносини не виникають. А от, решта фізичних і юридичних осіб, котрі наділені меншим обсягом повноважень і участь яких у процесі виконання - відбування покарання не завжди $\epsilon$ обов'язковою, $\epsilon$ іншими учасниками кримінально-виконавчих правовідносин [3, с. 36-37].

Свій погляд на зазначену проблематику у свій час висловив O. I. Осауленко, який визнаючи відмінності кримінально-виконавчих правовідносин, однією із них називає те, що суб'єктами перших можуть бути лише органи та установи виконання покарань, а також засуджені до різних видів кримінальних покарань [4, с. 139]. Крім цього, він із зазначеного приводу обгрунтовано доводить, що в юридичній літературі були спроби розширити коло суб'єктів кримінально-виконавчих правовідносин, включаючи до них, зокрема, прокуратуру, представників органів державної влади та місцевого самоврядування, різні громадські організації, членів сімей і близьких родичів засуджених, адвокатів, самодіяльні організації засуджених, що, на його думку, не можна вважати правильним підходом, навіть при дискусійності серед науковців даної проблематики [4, с. 140-141].

Серед представників останніх можна назвати М. В. Романова, який здійснивши класифікацію кримінально-виконавчих правовідносин, у змісті яких виокремив не їх суб'єктів, а учасників, а саме - кримінальновиконавчі установи та засуджених [5, c. 38]. Більш того, одним із видів цих правовідносин він назвав наглядові, тобто ті, що виникають з органами прокуратури [5, с. 38], чим тільки ускладнив розуміння між «суб'єктами» та «учасниками» кримінальновиконавчих правовідносин. Аналогічну позицію М. В. Романов висловив і в своїх подальших наукових розробках [6, с. 42].

У свою чергу, І. Г. Богатирьов, та О.В.Лісіцков взагалі не бачать відмінностей у поняттях «суб'єкти» та «учасники» кримінально-виконавчих правовідносин, стверджуючи при цьому, що суб'єктами цих правовідносин $\epsilon$ сторони, які володіють найбільшим обсягом суб'єктивних прав і обов'язків, встановлених нормами права [7, с. 71]. Виходячи з цього, на їх переконання, суб'єктами кримінально-виконавчих правовідносин, а також іншими учасниками цих правовідносин $є$ юридичні та фізичні особи, які володіють певними суб'єктивними правами i обов'язками, врегульованими нормами кримінально-виконавчого законодавства [7, с. 71-72].

Як показало вивчення зарубіжної наукової літератури, за кордоном 3 означених питань також немає одностайності. Так, російські учені 
А. І. Зубков та В. А. Уткін у своїх працях не виокремлюють окремо суб'єктів та учасників кримінальновиконавчих правовідносин, називаючи всіх юридичних і фізичних осіб, які забезпечують процес виконання та відбування кримінального покарання, учасниками такого виду суспільної діяльності [8, с. 18].

У той самий час, казахські науковці (Є. М. Бегалієв, А. Т. Байсетов та ін.) переконані, виконання покарання належить до виключної прерогативи (від лат. praerogativa - виключне право) [9, с. 463] уповноважених державних органів, які і є суб'єктами відповідних правовідносин [10, с. 19].

Порівняльно-правовий аналіз виконання та відбування покарань у зарубіжних державах, проведений групою науковців (I. Г. Богатирьов, I. М. Копотун, М. С. Пузирьов), також дає всі підстави стверджувати, що єдиним суб'єктом кримінальновиконавчих (пенітенціарних) правовідносин поряд із засудженими, $\epsilon$ органи та установи виконання покарань [11, с. 62-123].

У цілому ж, виходячи 3 проведеного аналізу та положень чинного кримінально-виконавчого законодавства України, слід констатувати, що до суб'єктів кримінальновиконавчих правовідносин варто віднести лише органи та установи виконання покарань, виключний перелік яких визначений в ст. 11 КВК України, та засуджених до тих чи інших кримінальних покарань (ст. 7 КВК). Всіх інших фізичних і юридичних осіб, включаючи й органи прокуратури (ст. 7 Закону України «Про прокуратуру»), необхідно вважати учасниками зазначених правовідносин, виходячи з того, що до їх повноважень безпосередньо не віднесено ні функції (ст. 2 Закону України «Про прокуратуру»), ні завдання (ст. 26 даного Закону) саме по виконанню покарання, тобто застосування до засудженого державного примусу такої процедури, що передбачає обмеження його прав, свобод і законних інтересів [12, с. 12]. У свою чергу, не можуть бути суб'єктами відбування будь-якого кримінального покарання, крім засуджених, інші особи $[12$, c. $12-13]$.

Саме тому не можна погодитись 3 тими дослідниками, які або тлумачать поняття «суб'єкти» та «учасники» одне через зміст іншого (А. П. Мозоль, Н. І. Мозоль, Л. Г. Юрковська) [13, с. 118-119], або взагалі не вводять в науковий обіг поняття «учасники кримінально-виконавчих правовідносин» (В. І.Селіверстов) [14, с. 38-39], або одночасно використовують зазначені вище поняття, не відокремлюючи поміж собою ні «суб'єктів», ні «учасників» цих правовідносин [15, с. 17-18].

Отже, якщо виходити із змісту завдання даного дослідження та викладених вище методологічних підходів з означеної проблематики, то органи прокуратури та, власне, прокурорів, які здійснюють нагляд за додержанням законів у виправних колоніях України (ст. 22 КВК та ст. 26 Закону України «Про прокуратуру»), слід останніх віднести до учасників кримінально-виконавчих правовідносин, позаяк результати їх діяльності у сфері виконання покарань тільки створюють належні умови для виконання та відбування кримінальних покарань, а не мають прямого (a, $\epsilon$ тільки опосередкований) причинного зв'язку з ефективністю та наслідками виконання кримінальних покарань в Україні. 
Додатковим аргументом 3 цього приводу є закріплена в ст. 2 Закону України «Про прокуратуру» така їі функція, як: нагляд за додержанням законів при виконанні судових рішень у кримінальних справах, а також при застосуванні інших заходів примусового характеру, пов'язаних 3 обмеженням особистої свободи громадян, а також у назві та змісті ст. 26 зазначеного Закону.

3 огляду цього, й оцінюється та робота, що здійснюють прокурори у сфері виконання покарань та яку в наукових джерелах відносять до кримінально-виконавчих аспектів їх діяльності [1, с. 55-86]. Поряд з цим, як слушно зауважив, зокрема, Ю. О. Новосад, зміст поняття «прокуратура як учасник кримінальновиконавчих правовідносин не включає в себе такі елементи, які характерні для суб'єкта правових відносин, а саме: це така функціонально визначена діяльність зазначеного державного органу, що встановлена в нормативно-правових актах та змістовно спрямована на створення відповідних умов для процесу виконання та відбування кримінальних покарань, шляхом здійснення прокурорського нагляду та координації дій інших учасників цих правовідносин, а також реалізації передбачених законом заходів, спрямованих на усунення, нейтралізацію, блокування тощо обставин, що детермінують порушення закону суб'єктами кримінально-виконавчих правовідносин $[1$, c. 85].

Виходячи з цього, та із змісту досліджуваної у цій роботі проблематики, можна констатувати, що зміст кримінально-виконавчої діяльності прокуратури у виправних колоніях України має складати: а) предмет нагляду, мова про який ведеться в ст. 22 КВК та ст. 26 Закону України «Про прокуратуру»;

б) встановлений порядок виконання - відбування покарання у виді позбавлення волі;

в) правовий статус засуджених до позбавлення волі та стан його реалізації у зазначених УВП, включаючи питання, що стосуються міжнародних стандартів поводження 3 цими особами;

г) законність видання та застосування відомчих нормативноправових актів у цих колоніях наказів, розпоряджень, вказівок тощо начальників зазначених УВП та осіб, які вправі здійснювати нормотворчу діяльність у сфері виконання покарань;

г) результати діяльності адміністрації даних колоній по усуненню, блокуванню, нейтралізації тощо детермінант, що сприяють порушенню принципів виконання та відбування покарань і кримінально-виконавчого законодавства, а також по реалізації вказівок прокурорів щодо їх ліквідаціï.

Такий висновок грунтується на положеннях:

1. Статті 26 Закону України «Про прокуратуру», у якій визначено зміст нагляду за додержанням законів у виправних колоніях та права прокурорів, які його здійснюють, а саме:

a) у будь-який час за посвідченням, що підтверджує займану посаду, відвідувати місця тримання затриманих, попередньо ув'язнених, установи, де перебувають особи, до яких застосовані примусові заходи медичного або виховного характеру, та будь-які інші місця, до яких доставлено осіб з метою складання прото- 
колу про адміністративне правопорушення чи в яких особи примусово тримаються згідно з судовим рішенням або рішенням адміністративного органу.

У виправних колоніях України, як це випливає зі змісту кримінально-виконавчого законодавства, до таких місць тримання засуджених відносяться, зокрема:

- житлові приміщення; робочі місця; їдальні; медичні частини; бібліотеки та інші об'єкти забезпечення життєдіяльності засуджених (ст. ст. 115-118 КВК; розділ XXIII Правил внутрішнього розпорядку установ виконання покарань (ПВР УВП);

- дисциплінарні ізолятори (ДІ30); приміщення камерного типу (ПКТ); одиничні камери (ОК) (ст. ст. 132, 134 КВК); розділ ХХІ ПВР УВП); а також карцери у СІ30, у які поміщуються у тому числі засуджені до позбавлення волі, залишені для роботи 3 господарського обслуговування слідчого ізолятора (ст. 89 КВК), або тимчасово залишені в СІ30 засуджені до позбавлення волі, або переведені особи цієї категорії з арештного дому, виправного центру, дисциплінарного батальйону або колонії до слідчого ізолятора в порядку, встановленому КПК (ст. 90 КВК);

- дільниці соціальної адаптації, які розміщені за межами виправних колоній, а також окремі виробничі об'єкти за межами цих УВП та інші об'єкти (наприклад лікарні територіальних органів охорони здоров'я, у яких тимчасово перебувають засуджені у зв'язку з необхідністю надання невідкладної медичної допомоги (ст. 116 КВК) або в яких здійснюється примусове лікування цих осіб (ст. 117 КВК; розділ XXII ПВР УВП);
- інші об'єкти, на яких можуть перебувати засуджені до позбавлення волі (кімнати короткострокових та довгострокових побачень цих осіб 3 родичами та іншими особами (ст. 110 КВК; розділ XIV ПВР УВП); приміщення, де засуджені отримують посилки та передачі (ст. 108 КВК; розділ ХІІ ПВР УВП; ін.)).

Цікавими у зв'язку з цим $\epsilon$ наступні офіційні статистичні дані, що стосується змісту зазначеної проблематики: тільки у 2016 році засудженні до позбавлення волі на законних підставах перебували на 284 окремих виробничих об'єктах, що були розташовані за межами виправних колоній; на 3-х тимчасових і короткочасних таких об'єктах; 3406 об'єктах лікувальних закладів Міністерства охорони здоров'я (МО3) України, а також на 8034 об'єктах, на яких здійснювалось медичне обстеження та стаціонарне лікування в медичних закладах МО3 України [16, с. 27].

Але ще більш тривожними, та такими, що мають пряме відношення до наслідків прокурорського нагляду за дотриманням законів у виправних колоніях, $\epsilon$ наступні відомості про об'єкти перебування засуджених до позбавлення волі, а саме:

- якщо у п. 3 розпорядження Кабінету Міністрів України від 13 вересня 2017 року № 654-р, яким була схвалена Концепція реформування (розвитку) пенітенціарної системи України, було зазначено, що міністерству юстиції слід забезпечити подальше реформування пенітенціарної системи України шляхом впровадження в практику кримінальновиконавчих установ міжнародного досвіду пенітенціарної діяльності та вимог європейських стандартів у сфері виконання покарань і пово- 
дження із засудженими, то у самій Концепції не сказано жодного слова з цього приводу, що свідчить про формалізм у даному сенсі запланованих заходів;

- у 2016 році в експлуатації залишались будівлі CI30, які були побудовані більш як 200 років тому, або 12 \% від загальної кількості слідчих ізоляторів в Україні (12 CI30 та 17 УВП з функціями СІ30); від 100 до 200 років тому - 58 \%; від 50 до 100 років тому - $14 \%$; від 10 до 50 років - $14 \%$ [17], тобто об'єкти, які неналежним чином забезпечували реалізацію засудженими до позбавлення волі своїх природніх прав і законних інтересів та не відповідали вимогам міжнародних стандартів поводження з цими особами;

- у незадовільному стані знаходилось 90 \% наявних комплексних технічних засобів охорони периметрів та 33 \% інших типів інженернотехнічних засобів охорони та нагляду виправних колоній і CI30 [17], не забезпечуючи таким чином право засуджених до позбавлення волі на особисту безпеку (ст. 10 КВК).

Таким чином, здійснюючи на протязі майже 30 років з часів незалежності України нагляд за додержанням законів у сфері виконання покарань, прокурори не в повній мірі використали існуючі у них правові можливості, спрямовані на вирішення зазначених проблем, опосередковано сприяючи при цьому порушенню основоположних прав і свобод засуджених і ув'язнених під варту;

б) відповідно до положень п. 2 ч. 1 ст. 26 Закону України «Про прокуратуру», прокурори вправі також опитувати осіб, які перебувають у місцях, зазначених у пункті 1 цієї частини, з метою отримання інфор- мації про умови їх тримання та поводження 3 ними, ознайомлюватися 3 документами, на підставі яких ці особи тримаються в таких місцях, засуджені або до них застосовано заходи примусового характеру.

При цьому, слід зазначити, що прокурори, здійснюючи свої повноваження у виправних колоніях, не вправі використовувати визначені у Законі України «Про оперативнорозшукову діяльність» форми, методи та засоби негласної роботи, навіть при тому, що однією з функцій прокуратури, що визначена в ст. 2 Закону України «Про прокуратуру», є нагляд за додержанням законів органами, що проводять оперативно-розшукову діяльність, дізнання та досудове слідство, позаяк прокурори не відносяться до суб'єктів ОРД, виключний перелік яких визначений в ст. 5 Закону України «Про оперативно-розшукову діяльність»;

в) крім цього, як це витікає із змісту п. 3 ч. 1 ст. 26 Закону України «Про прокуратуру», прокурори, які здійснюють нагляд за дотриманням законів у виправних колоніях, вправі знайомитись $з$ матеріалами, отримувати їх копії, перевіряти законність наказів, розпоряджень, інших актів відповідних органів і установ та в разі невідповідності законодавству вимагати від посадових чи службових осіб їх скасування та усунень порушень закону, до яких вони призвели, а також скасовувати незаконні акти індивідуальної дії.

Зокрема, тільки у 2015 році було внесено 13 тис. 250 документів прокурорського реагування, за результатами розгляду яких із установ попереднього ув'язнення, карцерів, ДІЗО та ПКТ за ініціативи прокурорів 
звільнено 198 незаконно утримуваних осіб $[18$, с. 130$]$.

Висновки. Таким чином, виходячи 3 результатів проведеного у цій роботі дослідження, слід констатувати, що роль прокуратури як учасника кримінально-виконавчої діяльності в реалізації міжнародних стандартів поводження із засудженими у виправних колоніях об'єктивно залежить та обумовлена як змістом кримінальновиконавчої політики України, так i ефективністю іiі реалізації, у першу чергу, на нормативно-правовому рівні, що варто врахувати при визначенні критеріїв оцінки результатів нагляду за дотриманням законів, який здійснюють прокурори у сфері виконання покарань та пробації.

\section{Список використаних джерел}

1. Новосад Ю. О. Прокуратура України як учасник кримінально-виконавчої діяльності: монографія. Луцьк : ПрАТ «Волинська обласна друкарня», 2019. 462 с.

2. Уголовно-исполнительное право: учебник / А. С. Михлин, П. Г. Пономарев, И. В. Шмаров и др.; под ред. И. В. Шмарова. Москва: Новый Юрист, 2003. 506 с.

3. Гель А. П., Семаков Г. С., Яковець І. С. Кримінально-виконавче право України: навч. посібник / за ред. проф. А. Х. Степанюка. Київ : Юрінком Інтер, 2008. 624 с.

4. Кримінально-виконавче право України: підручник / О. М. Джужа, І. Г. Богатирьов, О. Г. Колб, В. В. Василевич та ін.; за заг. ред. докт. юрид. наук, проф. О. М. Джужи, О. Г. Колба. Київ : Атіка, 2010. 752 с.

5. Кримінально-виконавче право: підруч. для студ. юрид. спец. вищ. навч. закл. / за ред. А. Х. Степанюка. Харків : Право, 2006. 256 с.

6. Кримінально-виконавче право: підруч. для студ. юрид. спец. вищ. навч. закл. / за ред. А. Х. Степанюка. Харків : Право, 2011. 256 с.

7. Богатирьов І. Г., Лісіцков О. В. Кримінально-виконавче право: підручник: модульно-рейтинговий курс для студентів, курсантів та слухачів вищ. юрид. навч. закладів III-IV рівнів акредитації: 2-ге вид. Київ : Дакор, 2014. 376 с.

8. Уголовно-исполнительное право России: теория, законодательство, международные стандарты, отечественная практика конца XIX - начала XXI века: учебник для вузов / под ред. д.ю.н., проф. А. И. Зубкова. 3-е изд., перераб. и доп. Москва: Норма, 2005. $720 \mathrm{c}$.

9. Булыко А. Н. Большой словарь иностранных слов. 35 тысяч слов. Изд. 3-е, испр., перераб. Москва : Мартин, 2010. 704 с.

10. Понятие, признаки, система и наказания по уголовному законодательству Украины и Республики Казахстан: учебн. пособ. / М. В. Палий, Е. Н. Бегалиев, Е. С. Назымко и др.; под ред. В. Н. Бессчасного. Киев : КНТ, 2009. 232 с.

11. Порівняльне кримінально-виконавче право: навч. посіб. / І. Г. Богатирьов, I. М. Копатун, М. С. Пузирьов; за заг. ред. І. Г. Богатирьова. Київ : Ін-т кримінальновикон. служби, 2013. 140 с.

12. Кримінально-виконавче право: підручник / Б. М. Головкін, А. Х. Степанюк, О. Г. Колб та ін.; за ред. Б. М. Головкіна та А. Х. Степанюка. 2-ге вид. перероб. і доповн. Харків : Право, 2019. 288 с.

13. Словник юридичних термінів: навчально-наукове видання / уклад.: А. П. Мозоль, Н. І. Мозоль, Л. Г. Юрковська. Київ : МП «Леся», 2014. 192 с.

14. Уголовно-исполнительное право: Учеб. для юрид. вузов / под ред. Д.ю.н., проф. В. И. Селиверстова. 6-е изд., исправ. и доп. Москва : ИД «Юриспруденция», 2007. 392 с.

15. Бриллиантов А. В., Курганов С. И. Уголовно-исполнительное право в вопросах, ответах и схемах: учеб. пособ. Москва : Проспект, 2012. 224 с. 
16. Про стан правопорядку, ізоляції та нагляду, діяльність підрозділів охорони, пожежної безпеки та воєнізованих формувань Державної кримінально-виконавчої служби України у 2016 році: інформ. бюлетень. Київ: Департамент ДКВС Міністерства юстиції України, 2017. 34 с.

17. Про схвалення концепції реформування (розвитку) пенітенціарної системи України: розпорядження Кабінету Міністрів України від 13 вересня 2017 року № 654-p. URL: https://zakon.rada.gov.ua./laws/show/654-2017-p. (дата звернення: 22.02.2020).

18. Дудко Є. В. Прокуратура України як учасник кримінально-виконавчих правовідносин: дис... канд. юрид. наук: 12.00.08. Київ : Нац. акад. внутр. справ, 2015. 297 с.

\section{References}

Novosad, Yu. O. (2019). Prokuratura Ukrainy yak uchasnyk kryminalno-vykonavchoi diialnosti. Lutsk: PrAT «Volynska oblasna drukarnia» [in Ukrainian].

Hel, A. P., Semakov, H. S., Yakovets, I. S. (2008). Kryminalno-vykonavche pravo Ukrainy. Kyiv: Yurinkom Inter [in Ukrainian].

Dzhuzha, O. M., (red.). (2010). Kryminalno-vykonavche pravo Ukrainy. Kyiv: Atika [in Ukrainian].

Stepaniuk, A. Kh. (2006). Kryminalno-vykonavche pravo. Kharkiv: Pravo, [in Ukrainian]. Stepaniuk, A. Kh. (2006). Kryminalno-vykonavche pravo. Kharkiv: Pravo, [in Ukrainian].

Bohatyrov, Y. H., Lisitskov, O. V. (2014). Kryminalno-vykonavche pravo. Kyiv: Dakor [in Ukrainian].

Zubkov, A. Y. (2005). Uholovno-yspolnytelnoe pravo Rossyy: teoryia, zakonodatelstvo, mezhdunarodne standart, otechestvennaia praktyka kontsa KhIKh- nachala KhKhI veka: Moskva: Norma [in Russian].

Bulyko, A. N. (2010). Bolshoi slovar ynostrannykh slov. 35 tysiach slov. Moskva: Martyn [in Russian].

Palyi, M. V., Behalyev, E. N., Nazymko, E. S. (2009). Poniatye, pryznaky, systema y nakazanyia po uholovnomu zakonodatelstvu Ukrayny y Respublyky Kazakhstan. Kyev: KNT [in Russian].

Bohatyrov, I. (2013). Porivnialne kryminalno-vykonavche pravo. Kyiv: In-t kryminalno-vykon. Sluzhby [in Ukrainian].

Holovkin, B. M., Stepaniuk, A. Kh. (red.). (2019). Kryminalno-vykonavche pravo. Kharkiv: Pravo [in Ukrainian].

Slovnyk yurydychnykh terminiv. (2014). Kyiv: MP «Lesia» [in Ukrainian]

Selyverstov, V. Y. (red.). (2007). Uholovno-yspolnytelnoe pravo. Moskva: YD «Iurysprudentsyia» [in Russian].

Bryllyantov, A. V., Kurhanov, S. Y. (2012). Uholovno-yspolnytelnoe pravo v voprosakh, otvetakh y skhemakh. Moskva: Prospekt [in Russian].

Dudko, Ye. V. (2015). Prokuratura Ukrainy yak uchasnyk kryminalno-vykonavchykh pravovidnosyn (Dys... kand. yuryd. nauk) Kyiv: Nats. akad. vnutr. Sprav [in Ukrainian]. 
A. Kolodchina, Post-graduate student of the Department of Security, Law Enforcement and Anti-Corruption Activity of PJSC "Higher Educational Institution "Interregional Academy of Personnel Management"

\section{Role of prosecutor's office as participant criminal and executive activity in implementation of the international standards of treatment of convicts in corrective labor colonies of Ukraine}

In article with "it is established essence and content of activity of prosecutor's office as participant of criminal and executive legal relationship, with implementation of the international standards concerning the convicts imprisoned and also its role in prevention brutal and degrading treatment and punishment concerning these persons is defined.

The need to address this issue in this paper is due to several circumstances:

a) first, the critical condition in the sphere of execution of penalties of Ukraine and which acts as one of the determinants, which negatively affects the efficiency of execution and serving of sentences in the form of imprisonment and, in particular, reduces the level of protection of fundamental rights, freedoms and legal the interests of persons held in correctional colonies;

b) secondly, the objective need to involve all the subjects and participants of criminal enforcement activities in the process of reforming the activity of bodies and institutions of execution of punishment of Ukraine, one of the tasks of which is to ensure the implementation of international standards of treatment of prisoners, deprived of liberty in practice;

c) third, the new status of the prosecutor's office, which it received as a result of the amendment of the Constitution of Ukraine and the Law of Ukraine "On the Prosecutor's Office", which, in turn, adversely affected the effectiveness of supervising the observance of laws in the correctional colonies of Ukraine;

d) fourthly, the tasks arising from the content of Ukraine's international commitments, in particular, the approximation of national legislation to that of the European Union;

e) fifth, the theoretical rethinking of the content of criminal activity in Ukraine in the current context and the development of adequate science-based measures to address these issues.

In this context, the question of the prosecutor's office's role in the implementation of international standards for the treatment of prosecutors in the sense of criminal-enforcement activity, who oversee compliance with the laws in the sphere of punishment and probation, is quite relevant issue (Art. 22 of the KVC and Art. 26 of the Law of Ukraine "On the Prosecutor's Office").

It was these circumstances that led to the choice of the topic of this article and determined its main task - to develop a set of scientifically substantiated measures aimed at enhancing the role of the prosecutor's office in bringing the current criminal law of Ukraine on specified issues to the requirements of the legislation of the European Union.

Keywords: international standards; condemned; the prosecutor's office; imprisonment; punishment; handling; prevention. 